\title{
EXPERIMENTAL ANALYSIS ON REINFORCED ALUMINIUM METAL MATRIX WITH BORON CARBIDE, GRAPHITE AND FLY ASH CHEMICAL COMPOSITES
}

\author{
S. Nallusamy ${ }^{1, *}$, S. Saravanan ${ }^{2}$, V. Kannarasu ${ }^{3}$ and M. Rajaram Narayanan ${ }^{4}$ \\ $1,2,3$ Department of Mechanical Engineering, Dr. M G R Educational and Research Institute, \\ Chennai-600095, Tamilnadu, India \\ ${ }^{4}$ Department of Mechanical Engineering, Mount Zion College of Engineering, \\ Kerala- 689649, India \\ *E-mail: ksnallu@gmail.com
}

\begin{abstract}
The objective of this research is to perform an experimental study on the tribological behavior of Al-7075 alloy reinforced with boron carbide $\left(\mathrm{B}_{4} \mathrm{C}\right)$, graphite $(\mathrm{Gr})$ and fly ash. The reinforcements added to aluminium alloy in three different compositions like $\mathrm{B}_{4} \mathrm{C}$ at $3 \mathrm{wt} \% / \mathrm{Gr}$ at $3 \mathrm{wt} \% / \mathrm{fly}$ ash at $6 \mathrm{wt} \%, \mathrm{~B}_{4} \mathrm{C}$ at $3 \mathrm{wt} \% / \mathrm{Gr}$ at $4 \mathrm{wt} \% / \mathrm{fly}$ ash at $7 \mathrm{wt} \%$ and $\mathrm{B}_{4} \mathrm{C}$ at $3 \mathrm{wt} \% / \mathrm{Gr}$ at $5 \mathrm{wt} \% / \mathrm{fly}$ ash at $8 \mathrm{wt} \%$. The composites were fabricated through stir casting process. Hardness and wear tests were conducted for all three different composites using Brinell hardness testing machine and pin on disc wear test apparatus respectively. The inverted microscope examination was also carried out to check the microstructural view of the specimens and it was observed that the reinforcement was uniformly distributed in the primary matrix without agglomeration. From the experimental results, it was found that $\mathrm{B}_{4} \mathrm{C}$ at $3 \mathrm{wt} \% / \mathrm{Gr}$ at $5 \mathrm{wt} \% /$ fly ash at $8 \mathrm{wt} \%$ composite specimen has shown better results than other two composition specimens and may suggest for automobile industries .
\end{abstract}

Keywords: Composites, Al-7075, B ${ }_{4} \mathrm{C} / \mathrm{Gr} / \mathrm{Fly}$ ash, Microstructure, Tribological Behaviour

(c) RASĀYAN. All rights reserved

\section{INTRODUCTION}

The aluminium based composites are being used in the field of marine, aerospace and automobile industries due to their improved strength, stiffness and wear resistance properties. Composites are heterogeneous in nature which is created by the assembly of two or more components with fillers or reinforcing fibers and a compactable matrix. Through an experimental investigation, the wear and mechanical behavior of reinforced aluminium matrix hybrid composites (AMHC) were carried out. The results showed that the effect of graphite on the hardness becomes less significant with the content of rice husk ash greater than $50 \%$ but it was noticed that the wear resistance was decreased when the graphite content increases from 0.5 to $1.5 \mathrm{wt} \% .^{1-3}$ In the earlier research articles, it was concluded that the addition of up to $15 \%$ fly ash increases the tensile strength of the composite. But with the further addition of fly ash leads to decreases the tensile strength..$^{4-6}$ The addition of graphite can give the smooth surface of the machining and specific wear rate decrease with increasing percentage of fly ash up to $15 \%$. Aluminium7075 alloy has always been used as a matrix material for its excellent tribological properties coupled with good formability. Reinforcement is added to increase its mechanical and tribological properties. ${ }^{7,8}$ In an experimental analysis, the various mechanical behaviors of aluminium composites were investigated and found that the $\mathrm{TiC}$ addition enhanced the damage resistance. From the results, it was found that $9 \mathrm{wt} \% \mathrm{TiC}$ composite is the best composition as compared with other compositions. ${ }^{9-11}$ The key role players to control the wear properties of the composites is the mechanically mixed layer formed on the worn surface of the composite. Improved load and sliding velocity increases the wear magnitude and frictional force and also slurry erosive wear resistance may be increased with increased content of fly ash. The creation of passive layer on the surface of the slurry erosive specimens decreased wear loss by forming a protective layer against the impact of the slurry. ${ }^{12,13}$ The ultimate tensile strength of Aluminium metal matrix composites were increased with increased rotational and traverse speed of the tool. The best possible

Rasayan J. Chem., 10(4), 1368-1373(2017)

http://dx.doi.org/10.7324/RJC.2017.1041910 
volume fractions of complex reinforcements in $5083 / \mathrm{Gr} / \mathrm{SiC} / \mathrm{ZrO}_{2}$ aluminum matrix hybrid composites were found with $10 \% \mathrm{Gr}+5 \% \mathrm{ZrO}_{2}$ for better tensile strength. ${ }^{14-17} \mathrm{In}$ another experiment, it was suggested that the wear resistance of the composites were increased with the addition of $\mathrm{Al}_{2} \mathrm{O}_{3}$ particle content and the rate of wear is significantly less as compared to pure matrix material. ${ }^{18-20}$ An experimental analysis was carried out on ten metal matrix composites produced by new powder injection technique where the toughness of the composite was mainly controlled by the precipitated segments. From the results, it was observed that cracks were always instigated during the matrix interfaces and depending upon the particle adhesion. ${ }^{21,} 22$ In another experimental investigations it was found that $\%$ of reinforcement the different parameters like sliding speed, distance etc may influence the wear rate of Al$\mathrm{SiC}-\mathrm{Gr}$ and $\mathrm{Al}-\mathrm{Gr}$ composites. In tribological behavior, Al-SiC-Gr hybrid composites are considered as better substitutes to $\mathrm{Al}-\mathrm{Gr}$ and $\mathrm{Al}-\mathrm{SiC}$ composites due to its superior wear resistance. ${ }^{23,24}$ The mechanical properties of $\mathrm{TiB}_{2}$ and $\mathrm{Mg}_{2} \mathrm{Si}$ hybrid composite have much advancement as compared with $\mathrm{TiB}_{2} / \mathrm{Al}$ composite, the yield stress and ultimate tensile strength (UTS) have also been improved respectively with dramatically decreased ductility. ${ }^{25,}{ }^{26}$ Hardness and tensile strength increased with increasing weight percent of the reinforcing phase but the strength and hardness dropped slightly with an increase in groundnut shell ash (GSA) content in the reinforcing phase. The percentage reduction in hardness and strength achieved in GSA containing composites were lower than rice husk ash (RHA), bamboo leaf ash (BLA) reinforced aluminium hybrid composites reported in previous work. ${ }^{27,28}$ The adequate selection of the chemical composition of aluminium matrix alloy is very important and has an influence on the structure of the interface between ceramic reinforcement. This allows obtaining a stable suspension and forming of the composite with casting method. ${ }^{29,30}$ Through an experimental analysis it was found that, the mechanical properties of the composites are also much subjective with weight fractions of the composite. The tensile strength was calculated with different weight fractions of $\mathrm{SiC}$ and $\mathrm{SiC} / \mathrm{Gr}$ reinforced composites and observed the maximum tensile strength at $15 \mathrm{wt} \%$ of $\mathrm{SiC} / \mathrm{Gr}$ composite. ${ }^{31,32}$ Based on the literature, a study was carried out to find out the tribological behavior of aluminium metal matrix reinforced with $\mathrm{B}_{4} \mathrm{C}, \mathrm{Gr}$ and fly ash with different compositions.

\section{EXPERIMENTAL}

\section{Sample preparation}

The stir casting method was used develop the reinforcement metal matrix composites with the temperature of stir casting furnace was maintained at $8000^{\circ} \mathrm{C}$. Boron Carbide $\left(\mathrm{B}_{4} \mathrm{C}\right)$, graphite $(\mathrm{Gr})$ and fly ash were first put into the crucible and the furnace is closed. After twenty minutes, the metals were verified for their molten state and after the confirmation, the metals such as boron carbide, graphite, and fly ash were put inside and the furnace was closed. After 15 to 20 minutes, the boron carbide, graphite and fly ash powder was added and the aluminium stirrer was set to $500 \mathrm{rpm}$, it oscillates by about 700 $\mathrm{rpm}$. After the stirrer is rotated for about five minutes, the stirrer was stopped and the molten metal was taken out. It was kept in cooling nature for about two hours and the following Table-1 shows the various process parameters considered for the fabrication of composites.

Table-1: Fabrication Process Parameters

\begin{tabular}{c|c|c|c|c|c|c|c}
\hline $\begin{array}{c}\text { Base } \\
\text { Material }\end{array}$ & $\begin{array}{c}\mathrm{B}_{4} \mathrm{C} \\
(\%)\end{array}$ & $\begin{array}{c}\text { Gr } \\
(\%)\end{array}$ & $\begin{array}{c}\text { Fly Ash } \\
(\%)\end{array}$ & $\begin{array}{c}\text { Stir Speed } \\
(\mathrm{rpm})\end{array}$ & $\begin{array}{c}\text { Stir Time } \\
(\text { mins })\end{array}$ & $\begin{array}{c}\text { Pouring } \\
\text { Temp. }\left({ }^{\circ} \mathrm{C}\right)\end{array}$ & $\begin{array}{c}\text { Preheated } \\
\text { Temp. }\left({ }^{\circ} \mathrm{C}\right)\end{array}$ \\
\hline $\mathrm{Al}-7075$ & 3 & 3 & 6 & 500 & 5 & 800 & 400 \\
\hline $\mathrm{Al}-7075$ & 3 & 4 & 7 & 500 & 5 & 800 & 400 \\
\hline $\mathrm{Al}-7075$ & 3 & 5 & 8 & 500 & 5 & 800 & 400 \\
\hline
\end{tabular}

Al-7075 is an alloy with zinc as the primary alloying element. It has good strength comparable to many sheets of steel and average machinability but has less resistance to corrosion than many other aluminium alloys. It's relatively high-cost limits and used in applications where cheaper alloys are not suitable. Al7075 alloy includes 5.6-6.1\% zinc, 2.1-2.5\% magnesium and 1.2-1.6\% copper composition with less than a half percent of metals such as silicon, iron, manganese, titanium chromium etc. There are three different samples were prepared with various percentage of compositions like $3 \% \mathrm{~B}_{4} \mathrm{C}+3 \% \mathrm{Gr}+6 \%$ fly ash , $3 \%$ $\mathrm{B}_{4} \mathrm{C}+4 \% \mathrm{Gr}+7 \%$ fly ash and $3 \% \mathrm{~B}_{4} \mathrm{C}+5 \% \mathrm{Gr}+8 \%$ fly ash to carry out the experimental analysis. The 
RASĀYAN $J$. Chem.

Vol. 10 | No. 4 |1368-1373 | October - December | 2017

various chemical compositions of $\mathrm{Al}-7075$ and composition with reinforcements are tabulated in the following Table-2 and Table-3 respectively.

Table-2: Al-7075 Chemical Composition

\begin{tabular}{c|c|c|c|c|c|c|c|c|c}
\hline Element & $\mathrm{Si}$ & $\mathrm{Fe}$ & $\mathrm{Mn}$ & $\mathrm{Mg}$ & $\mathrm{Cr}$ & $\mathrm{Zn}$ & $\mathrm{Cu}$ & $\mathrm{Ti}$ & $\mathrm{Al}$ \\
\hline Composition (\%) & 0.5 & 0.6 & 0.4 & 2.5 & 0.15 & 5.5 & 1.6 & 0.2 & 88.5 \\
\hline
\end{tabular}

Table-3: Various Composition of Reinforcement

\begin{tabular}{c|c|c|c|c}
\hline Sample & $\begin{array}{c}\text { Al-7075 } \\
\text { Mass Value }(\mathrm{g})\end{array}$ & $\begin{array}{c}\mathrm{B}_{4} \mathrm{C} \\
\text { Mass Value }(\mathrm{g})\end{array}$ & $\begin{array}{c}\text { Gr } \\
\text { Mass Value }(\mathrm{g})\end{array}$ & $\begin{array}{c}\text { Fly ash } \\
\text { Mass Value }(\mathrm{g})\end{array}$ \\
\hline Specimen I & 713.61 & 21.81 & 19.45 & 12.87 \\
\hline Specimen II & 697.49 & 21.81 & 26.07 & 15.21 \\
\hline Specimen III & 681.31 & 21.81 & 32.57 & 17.29 \\
\hline
\end{tabular}

\section{RESULTS AND DISCUSSION}

The experimental investigations carried out on the distribution of reinforcement particles in aluminium metal matrix, hardness and microstructural analysis was done to find out the best alloy. The wear rate was calculated for the different compositions with various load and speed conditions. The wear rate of Al7075 alloy with $3 \mathrm{wt} \% \mathrm{~B}_{4} \mathrm{C} / 3 \mathrm{wt} \% \mathrm{Gr} / 6 \mathrm{wt} \%$ fly ash, $3 \mathrm{wt} \% \mathrm{~B}_{4} \mathrm{C} / 4 \mathrm{wt} \% \mathrm{Gr} / 7 \mathrm{wt} \%$ fly ash and $3 \mathrm{wt} \%$ $\mathrm{B} 4 \mathrm{C} / 5 \mathrm{wt} \% \mathrm{Gr} / 8 \mathrm{wt} \%$ fly ash compositions with a load of 2,5 and $7 \mathrm{~kg}$ were calculated and given in the following Table-4, Table-5, and Table-6 respectively.

Table-4: Results of Wear Rate for Al-7075 alloy with 3wt $\% \mathrm{~B}_{4} \mathrm{C} / 3 \mathrm{wt} \% \mathrm{Gr} / 6 \mathrm{wt} \%$ fly ash

\begin{tabular}{c|c|c|c|c|c|c}
\hline Load $(\mathrm{Kg})$ & $\begin{array}{c}\text { Speed } \\
(\mathrm{rpm})\end{array}$ & $\begin{array}{c}\text { Time } \\
(\mathrm{mins})\end{array}$ & $\begin{array}{c}\text { Initial } \\
\text { Weight }\end{array}$ & $\begin{array}{c}\text { Final } \\
\text { Weight }\end{array}$ & $\begin{array}{c}\text { Change in } \\
\text { Weight }\end{array}$ & $\begin{array}{c}\text { Wear Rate } \\
\left(\mathrm{mm}^{3} / \mathrm{m}\right)\end{array}$ \\
\hline 2 & 500 & 5 & 12 & 11.91 & 0.08 & 0.033 \\
\hline 5 & 500 & 5 & 11.92 & 11.81 & 0.11 & 0.045 \\
\hline 7 & 500 & 5 & 11.82 & 11.73 & 0.07 & 0.028 \\
\hline
\end{tabular}

Table-5: Results of Wear Rate for Al-7075 alloy with 3wt\% B ${ }_{4} \mathrm{C} / 4 \mathrm{wt} \% \mathrm{Gr} / 7 \mathrm{wt} \%$ fly ash

\begin{tabular}{c|c|c|c|c|c|c}
\hline Load $(\mathrm{Kg})$ & $\begin{array}{c}\text { Speed } \\
(\mathrm{rpm})\end{array}$ & $\begin{array}{c}\text { Time } \\
(\mathrm{mins})\end{array}$ & $\begin{array}{c}\text { Initial } \\
\text { Weight }\end{array}$ & $\begin{array}{c}\text { Final } \\
\text { Weight }\end{array}$ & $\begin{array}{c}\text { Change in } \\
\text { Weight }\end{array}$ & $\begin{array}{c}\text { Wear Rate } \\
\left(\mathrm{mm}^{3} / \mathrm{m}\right)\end{array}$ \\
\hline 2 & 500 & 5 & 10.5 & 10.42 & 0.08 & 0.035 \\
\hline 5 & 500 & 5 & 10.42 & 0.39 & 0.03 & 0.012 \\
\hline 7 & 500 & 5 & 10.39 & 10.27 & 0.11 & 0.048 \\
\hline
\end{tabular}

Table-6: Results of Wear Rate for Al-7075 alloy with 3wt\% B $\mathrm{B}$ C/5wt\% Gr/8wt\% fly ash

\begin{tabular}{c|c|c|c|c|c|c}
\hline Load $(\mathrm{Kg})$ & $\begin{array}{c}\text { Speed } \\
(\mathrm{rpm})\end{array}$ & $\begin{array}{c}\text { Time } \\
(\mathrm{mins})\end{array}$ & $\begin{array}{c}\text { Initial } \\
\text { Weight }\end{array}$ & $\begin{array}{c}\text { Final } \\
\text { Weight }\end{array}$ & $\begin{array}{c}\text { Change in } \\
\text { Weight }\end{array}$ & $\begin{array}{c}\text { Wear Rate } \\
\left(\mathrm{mm}^{3} / \mathrm{m}\right)\end{array}$ \\
\hline 2 & 500 & 5 & 12 & 11.95 & 0.05 & 0.022 \\
\hline 5 & 500 & 5 & 11.95 & 11.90 & 0.05 & 0.019 \\
\hline 7 & 500 & 5 & 11.90 & 10.27 & 0.11 & 0.047 \\
\hline
\end{tabular}

From the above results, it was found that, the wear rate increases during applied load increases which are clearly indicated in the above Fig.-1. During the initial stage, there is a little change in wear rate was found in the analysis. The rate of wear majorly depends on the rate of reinforcement added to the parent material of Al-7075. Also, it was seen that the higher rate of reinforcement lowers the wear rate appropriately.

\section{Brinell hardness number (BHN)}

The hardness values for different composite specimens were calculated with different weight percentages particles and sizes are tabulated in Table-7. Composite materials are characterized by an increased hardness compared to the unreinforced aluminium alloy. Brinell hardness values of composite specimens' 
shows an increase in hardness with an increase in reinforcement particles with a base material, for example, the hardness value for the specimen I of Al-7075 alloy with 3wt $\% \mathrm{~B}_{4} \mathrm{C} / 3 \mathrm{wt} \% \mathrm{Gr} / 6 \mathrm{wt} \%$ fly ash is 140 and $3 \mathrm{wt} \% \mathrm{~B}_{4} \mathrm{C} / 4 \mathrm{wt} \% \mathrm{Gr} / 7 \mathrm{wt} \%$ fly ash is 162 . The comparison chart for BHN value is shown in Fig.-2. From the figure, it was found that the reinforcements are added to increase the hardness value for the alloy. The results revealed that the composite with $3 \mathrm{wt} \% \mathrm{~B}_{4} \mathrm{C} / 5 \mathrm{wt} \% \mathrm{Gr} / 8 \mathrm{wt} \%$ fly ash has a maximum BHN value of 172 .

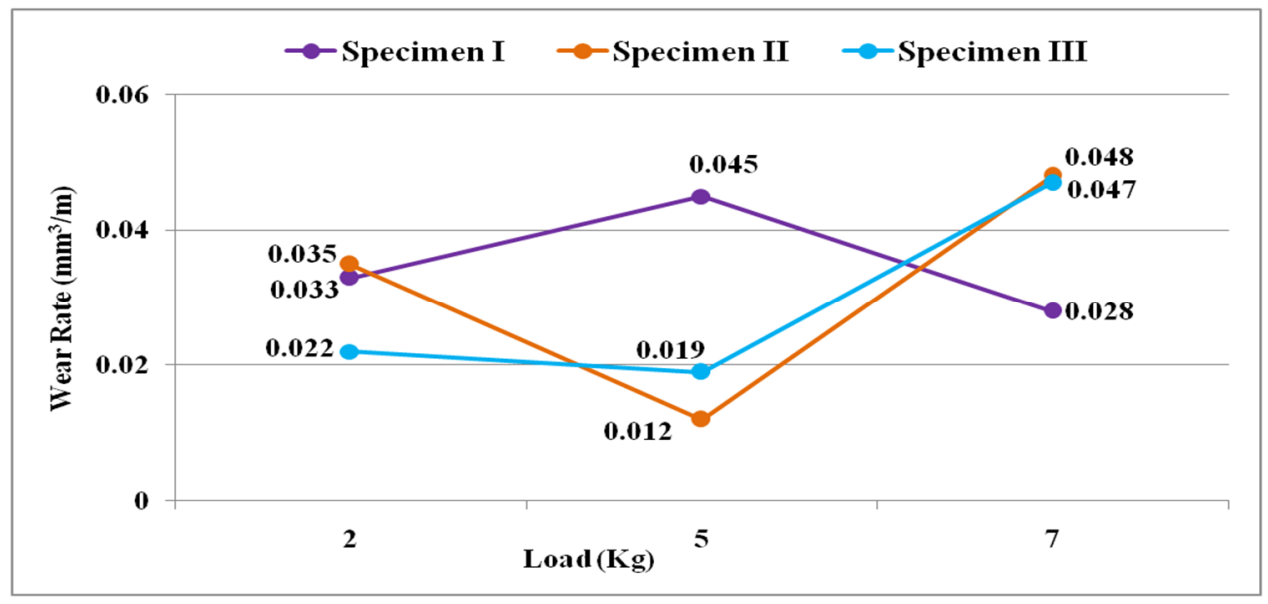

Fig.-1: Wear Rate Comparison Chart

Table-7: Hardness Values for Different Composites

\begin{tabular}{l|c|c|c|c|c}
\hline \multirow{2}{*}{ Specimen } & Base & \multicolumn{3}{|c|}{ Indentation } & \multirow{2}{*}{ BHN } \\
\cline { 3 - 5 } & Material & 1 & 2 & 3 & \\
\hline Specimen I & 7075 & 2.9 & 3.0 & 2.8 & 140 \\
\hline Specimen II & 7075 & 2.7 & 2.9 & 2.8 & 162 \\
\hline Specimen III & 7075 & 2.9 & 2.7 & 2.7 & 172 \\
\hline
\end{tabular}

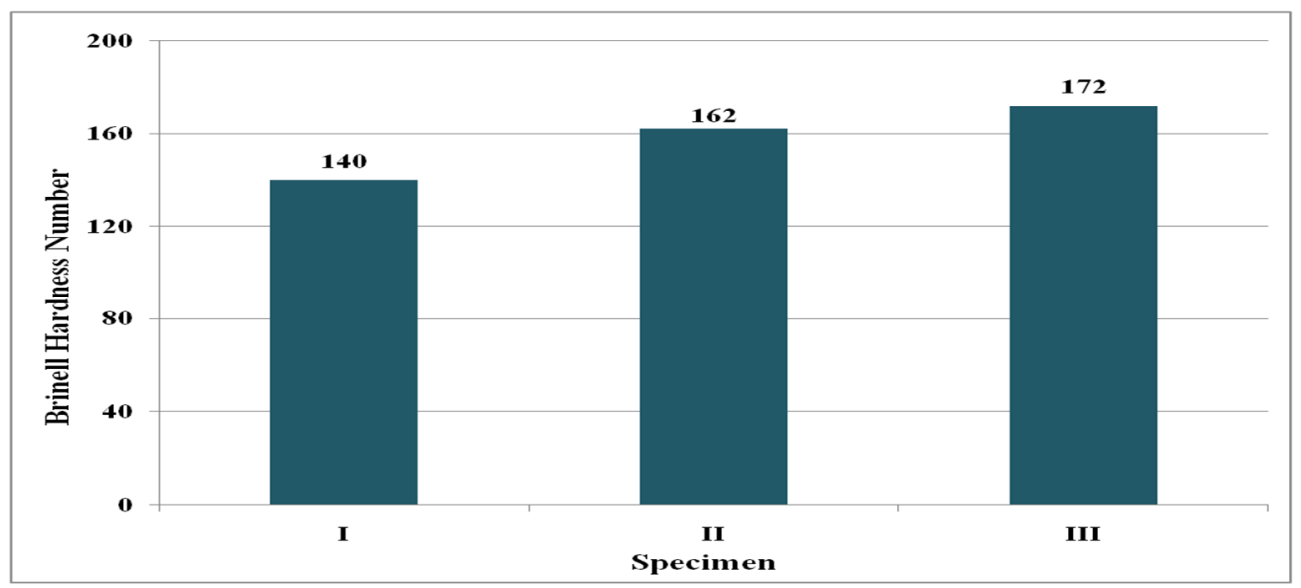

Fig.-2: BHN Comparison Chart for Different Specimens

\section{Microscope investigation}

An inverted microscope was used in this investigation to view the distribution of the reinforcement in the base metal of Al-7075. The specimen was etched by Keller's reagent and was immersed for about fifteen seconds. The microstructural views of the composites at 50X magnification with different compositions of $3 \mathrm{wt} \% \mathrm{Gr} / 6 \mathrm{wt} \%$ fly ash and $3 \mathrm{wt} \% \mathrm{~B}_{4} \mathrm{C}$, $4 \mathrm{wt} \% \mathrm{Gr} / 7 \mathrm{wt} \%$ fly ash and $3 \mathrm{wt} \% \mathrm{~B}_{4} \mathrm{C}$ and $5 \mathrm{wt} \% \mathrm{Gr} / 8 \mathrm{wt} \%$ fly ash and $3 \mathrm{wt} \% \mathrm{~B}_{4} \mathrm{C}$ are shown in the following Fig.-3, Fig.-4, and Fig.-5 respectively. From the microscopic images, it was seen that the reinforcements are dispersed uniformly the matrix in all the compositions. 
RASĀYAN J. Chem.

Vol. 10 | No. 4 |1368-1373 | October - December | 2017

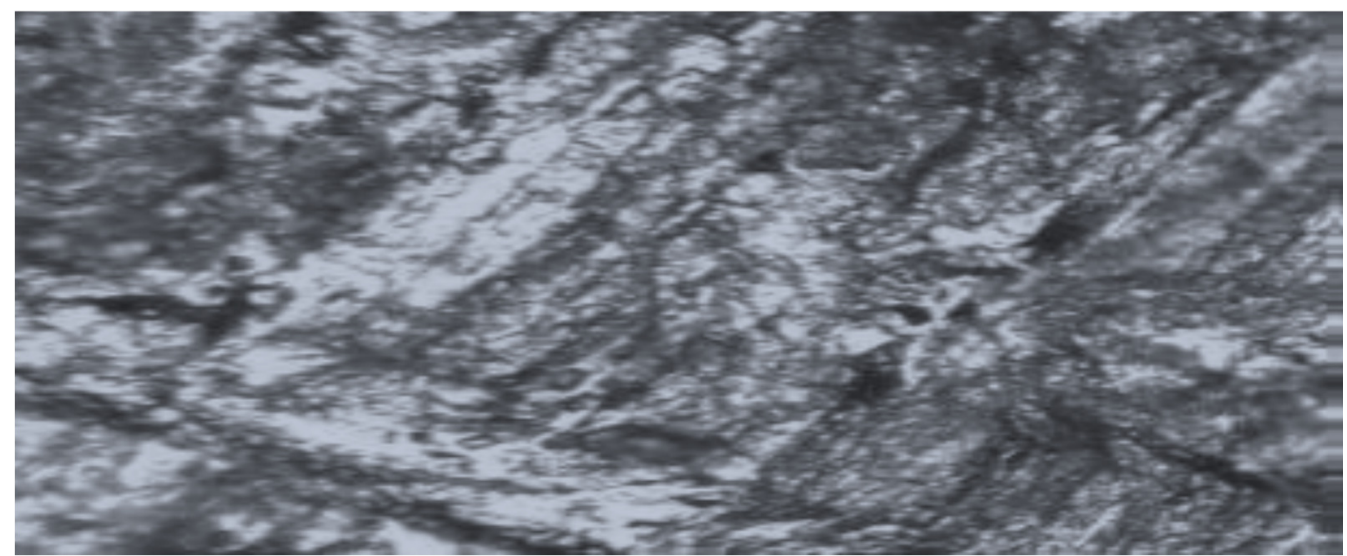

Fig.-3: Image for $3 \mathrm{wt} \% \mathrm{~B}_{4} \mathrm{C} / 3 \mathrm{wt} \% \mathrm{Gr} / 6 \mathrm{wt} \%$ fly ash

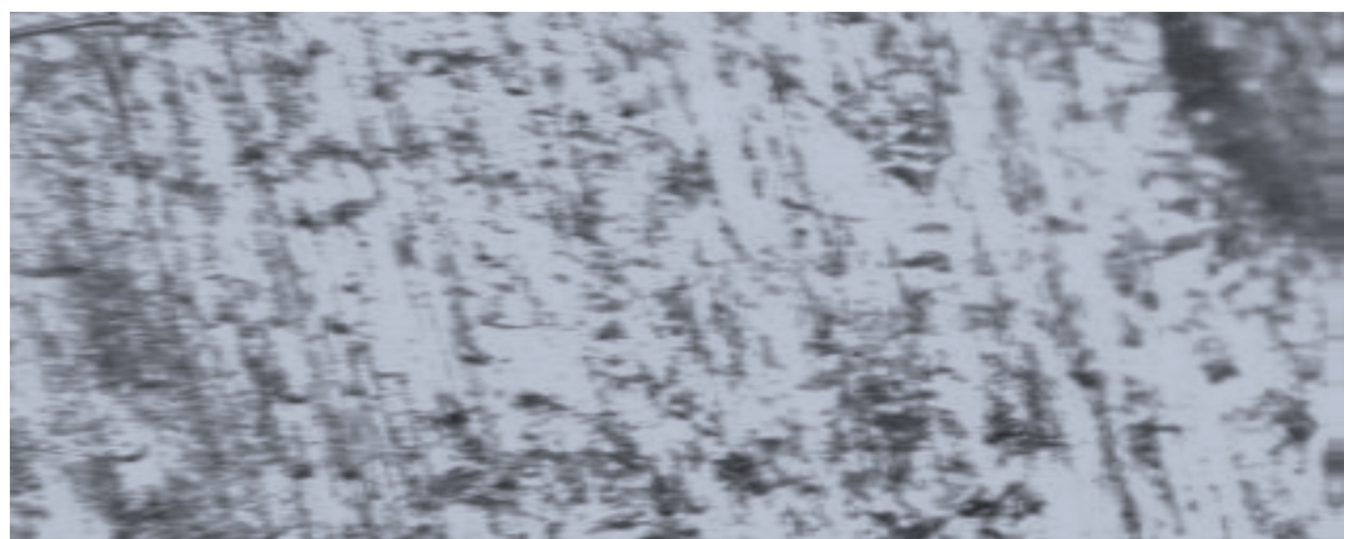

Fig.-4: Image for $3 \mathrm{wt} \% \mathrm{~B}_{4} \mathrm{C} / 4 \mathrm{wt} \% \mathrm{Gr} / 7 \mathrm{wt} \%$ fly ash

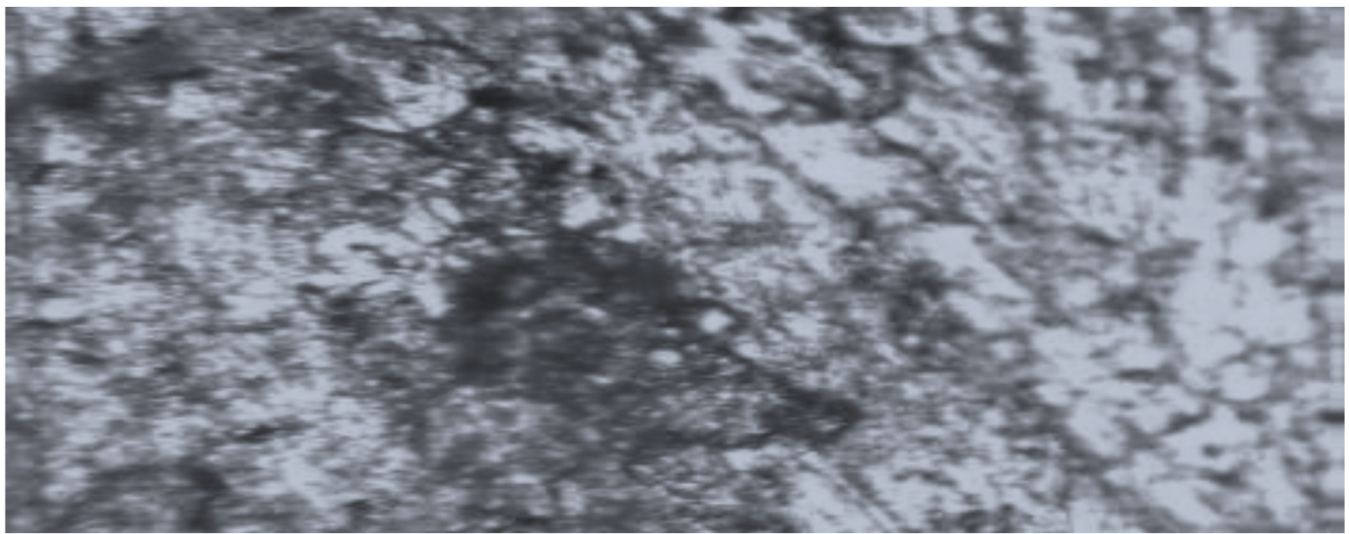

Fig.-5: Image for $3 \mathrm{wt} \% \mathrm{~B}_{4} \mathrm{C} / 5 \mathrm{wt} \% \mathrm{Gr} / 8 \mathrm{wt} \%$ fly ash

CONCLUSION

In this experimental analysis, there are three different composites with various compositions of reinforcements were prepared through stir casting process. From the analysis and results, the following conclusions arrived.

- It was found that the percentage of $\mathrm{B}_{4} \mathrm{C}, \mathrm{Gr}$ and fly ash has a direct relation with hardness and increase in addition of $\mathrm{B}_{4} \mathrm{C}, \mathrm{Gr}$ and fly ash restricts the deformation of the matrix material and improve the hardness.

- Reinforcement particle size shows a direct relationship with hardness and for a given weight 
RASĀYAN J. Chem.

Vol. 10 | No. 4 |1368-1373 | October - December | 2017

fraction of reinforcements, larger particle size offered higher hardness.

- The final results revealed that, the composite with $3 \mathrm{wt} \%$ of $\mathrm{B}_{4} \mathrm{C} / 5 \mathrm{wt} \%$ of $\mathrm{Gr} / 8 \mathrm{wt} \%$ of fly ash yield maximum BHN value of 172 .

- Wear resistance also significantly increased with increase in the content of reinforcement.

- From the results, it was found that addition of $3 \mathrm{wt} \%$ of $\mathrm{B}_{4} \mathrm{C} / 5 \mathrm{wt} \%$ of $\mathrm{Gr} / 8 \mathrm{wt} \%$ of fly ash specimen provides better tribological properties compared with other specimens.

\section{REFERENCES}

1. Kenneth Kanayo Alaneme and Kazeem Oladiti Sanusi, Engineering Science and Technology, an International Journal, 18(3), 416(2015)

2. S. Nallusamy and A. Karthikeyan, Indian Journal of Science and Technology, 9(35), 01(2016)

3. A. Karthikeyan and S. Nallusamy, Int. Journal of Engineering Research in Africa, 31, 36(2017)

4. Viney Kumara, Rahul Dev Guptab and N.K. Batrab, Procedia Materials Science, 6, 1365(2014)

5. S. Nallusamy and Gautam Majumdar, Int. Journal of Performability Engg., 12(3), 229(2016)

6. R. Suganthini Rekha, S. Nallusamy, R. Vijayakumar and S. Saravanan, International Journal of Applied Engineering Research, 10(62), 133(2015)

7. G. Ramanan, Dhas, Ramachandran and Samuel, Rasayan Journal of Chemistry, 10(2), 375(2017)

8. S. Nallusamy and A. Karthikeyan, Journal of Nano Research, 49, 01(2017)

9. Rajesh Prabha, N and Edwin Raja Dhas, J, Rasayan Journal of Chemistry, 10(3), 729(2017)

10. S. Nallusamy and Saurabh Kumar, Indian Journal of Science and Technology, 9(16), 01(2016)

11. S. Jeevanantham, N.M. Sivaram, D.S. Robinson Smart, S. Nallusamy and N. Manikanda Prabu, International Journal of Applied Engineering Research, 12(11), 2963(2017)

12. Alaneme and Olubambi, Journal of Materials Research and Technology, 2, 188(2013)

13. S. Nallusamy, International Journal of Engineering Research in Africa, 22, 112(2016)

14. Kurt Halil Ibrahim, Composites Part B Engineering, 93, 26(2016)

15. S. Nallusamy, International Journal of Engineering Research in Africa, 23, 181(2016)

16. Rajesh Prabha and Edwin Raja Dhas, Rasayan Journal of Chemistry, 10(3), 729(2017)

17. S. Nallusamy, Journal of Nano Research, 40, 105(2016)

18. Narasimha, G. Bala, M. Vamsi Krishna and R. Sindhu, Procedia Engineering, 97, 555(2014)

19. S. Nallusamy, Journal of Nano Research, 45, 155(2017)

20. S. Jeevanantham, David Rathnaraj, Robinson Smart, S. Nallusamy and N. Manikanda Prabu, Indian Journal of Science and Technology, 9(37), 01(2016)

21. Ibrahim, M.F., Ammar, Samuel and Soliman, Composites Part B Engineering, 04, 18(2015)

22. S. Nallusamy and J. Logeshwaran, Rasayan Journal of Chemistry, 10(3), 1050(2017)

23. S.Suresha and B.K.Sridhara, Composites Science and Technology,70(11), 1652(2010)

24. S. Nallusamy, International Journal of Performability Engineering, 12(2), 143(2016)

25. Gao, Qi, Shusen Wu and Sulin Lu, Journal of Alloys and Compounds, 08, 162(2015)

26. S. Nallusamy and Manikanda Prabu, International Journal of Nanoscience, 16(5\&6), 01(2017)

27. Kenneth Kanayo Alanemea and Olusola Joseph Ajayi, Journal of King Saud University - Engineering Sciences, 29(2), 172(2017)

28. S. Nallusamy, International Journal of Engineering Research in Africa, 21, 110(2015)

29. Anna J. Dolataa, Maciej Dyia and Sonia boczkal, Materials Today Proceedings, 3(2), 235(2016)

30. S. Nallusamy, Journal of Nano Research, 40, 105(2016).

31. Krishnaa M. Vamsi and Anthony. M.Xaviorb, Procedia Engineering, 97, 918(2014)

32. S. Nallusamy, Manikanda Prabu, K. Balakannan, and Gautam Majumdar, International Journal of Engineering Research in Africa, 16, 17(2015)

[RJC-1910/2017] 